\title{
RETÓRICA DE LOS MONSTRUOS MÍTICOS EN LA ANTIGÜEDAD GRIEGA
}

\author{
Henry Campos Vargas
}

\section{(c) $(7)(9)$}

Esta obra está bajo una licencia Creative Commons

Reconocimiento-No Comercial-Sin Obra Derivada 



\title{
RETÓRICA DE LOS MONSTRUOS MÍTICOS EN LA ANTIGÜEDAD GRIEGA
}

\author{
RHETORIC OF MYTHIC MONSTERS IN ANCIENT GREECE
}

\section{Henry Campos Vargas}

A doña Estébana Matarrita, mi profesora de griego

\begin{abstract}
RESUMEN
El presente artículo muestra cómo la construcción retórica de la monstruosidad fue objeto de la retórica antigua.

Palabras clave: retórica, monstruos, Aristóteles, belleza, Nietzsche.
\end{abstract}

ABSTRACT

This paper shows how the rhetorical construction of monstrosity was object of ancient rhetoric.

Key words: rhetoric, monsters, Aristotle, beauty, Nietzsche.

Las narraciones míticas son anteriores a las letras y se encuentran en el origen de las literaturas de todas las culturas del mundo. Así la antigua novela china Sueño del aposento rojo, el Zend Avesta, la Biblia, la Ilíada, las Mil y una noches.

Esto parece haber sido comprendido con toda claridad por Aristóteles en su Poética al establecer que la labor del escritor es componer mitos.

M.L. Henry Campos Vargas. Universidad de Costa Rica. Escuela de Filología, Lingüística y Literatura. Costa Rica.

Correo electrónico: hcamposv@yahoo.es

Recepción: 06- 04- 2015

Aceptación: 19- 06- 2015 
Contrario a lo que sostienen Borges o Bioy Casares, los mitos no son fantásticos, este carácter lo adquieren desde la perspectiva del mundo contemporáneo, particularmente merced al modernismo. Calificarlos así deviene, desafortunadamente, en un anacronismo.

Los mitos son reales para cada uno de los pueblos que los vieron nacer. Contra esta tesis han luchado miríadas de pensadores desde la antigua Grecia, el Renacimiento, el positivismo, el marxismo... Para quienes los viven, los mitos son parte de la vida en lo que se constituye como una visión mítica del mundo.

La asociación de lo mítico con lo fantástico no es reciente y ha permitido su asociación con lo irracional, tal y como ocurre en Platón, por ejemplo.

En efecto, en el tradicional sistema binario basado en la oposición racional/irracional, el mito ha corrido con la peor de las suertes al ser no solo asociado, sino identificado con lo irracional.

Ahora bien, lo monstruoso en la antigüedad aparece asociado al mito. Por las limitaciones de este estudio, que no pretende de ninguna manera agotar el tema, sino, más bien, ofrecer algunos aportes para profundizar en él; se considerará preponderantemente la monstruosidad en su aspecto físico, aunque pueda tener lugar en ámbitos como el moral y el conductual, por ejemplo.

Este tema constituye un verdadero problema para la retórica: ¿cómo conciliar este carácter monstruoso con la belleza literaria propuesta como desideratum? También lo es para la poética, ya que la mímesis y la mitopoyética parecen ser dos principios de constitución contradictorios.

En El origen de la tragedia, Nietzsche rescata esta interrogante, muy a propósito de estas reflexiones: “CCómo podría suscitar un goce estético lo horrible y lo monstruoso, materia del mito trágico?” (1952, p. 160).

\section{Lo monstruoso como juicio de valor}

Primero que todo, ha de reconocerse que la calificación de "monstruoso" presupone un sistema de valores, su jerarquización y un proceso de valoración. Esto permite explicar por qué, a través de distintas culturas, se aplica de manera diferente e, incluso, contradictoria.

La razón de ser de este proceso es compleja y excede los alcances del presente trabajo. Sin embargo, grosso modo, puede identificarse que esto obedece a procesos de control social (se califican de monstruosas ciertas conductas que deben ser evitadas, ejemplo paradigmático de esto es la prohibición del incesto). Asimismo, la monstruosidad asociada a los procesos de enseñanza incide en los sistemas de creencias de las personas (los dioses de pueblos conquistados se presentan como monstruosos por los conquistadores, de manera que, con el paso de los años, consiguen que los nativos abandonen sus divinidades autóctonas). En igual sentido, contribuyen a reforzar la cohesión del grupo, al describir como monstruosos los rasgos físicos de naciones o tribus rivales. Hasta puede servir como recurso mnemotécnico, pues tales imágenes impresionan de tal forma la mente y la memoria que permiten recordarlas con facilidad, lo cual es de suma importancia en las alegorías míticas.

La monstruosidad presupone un aspecto axiológico complejo, pues comprende aspectos estéticos y, cuando menos, a la vez éticos. Aprovecha aquello que se valora negativamente y, mediante su amplificación, se logra un efecto estético.

Por esto representaciones que a primera vista podrían considerarse monstruosas, como ciertos dioses positivos de la India, no son en realidad monstruos: la amplificación tiene lugar respecto de elementos que en sí mismos o simbólicamente han sido valorados positivamente. 
Así Ganesha, quien tiene la forma de elefante, es bello; aunque para los romanos los elefantes que enfrentaron contra Aníbal eran verdaderos monstruos.

En el ámbito humano, la aplicación del término "monstruo" a un individuo comporta su extrañamiento del grupo, un proceso que solo puede revertirse en la medida que su carácter de humano se vea reivindicado por el sujeto: las deformidades, de cualquier naturaleza que sean, se ven minimizadas en el tanto se aprecie a un sujeto como próximo (prójimo).

Efectivamente, lo monstruoso se incrementa proporcionalmente en función de la distancia que separe al sujeto-objeto del paradigma estético o conductual, por ejemplo que se haya asumido.

Por último, para concluir esta breve digresión, debe tenerse presente el principio retórico de acuerdo con el cual, las obras son signos de los modos de ser (249-250, I, 9.5, 1367b27-34).

Tal principio establece un vínculo profundo entre la ética y la ontología en la visión aristotélica: si un sujeto realiza acciones reprochables, es porque su naturaleza es reprochable.

\section{Los monstruos en la antigüedad griega}

Aunque a primera vista pareciera un paralogismo, lo cierto es que para el mundo antiguo la presencia de monstruos en sus hermosos poemas no representó un problema irresoluto. Por el contrario, la literatura heredada de los griegos y romanos nos muestra no solo cierto grado de naturalidad en el manejo de los monstruos sino, incluso, la búsqueda de satisfacer una especie de necesidad.

Una posible respuesta sería apelar a la conocida díada de lo apolíneo y lo dionisíaco. La propuesta nietzschiana es muy simple, al recurrir a una concepción metafísica del arte:

[...] el mito trágico tiene, precisamente, por objeto convencernos de que aun lo horrible y lo monstruoso no son más que un juego estético, que la Voluntad juega con ella misma en la plenitud eterna de su alegría

[...] El instinto dionisíaco, con su placer primordial aun ante el dolor, es la matriz común de que nacieron

la música y el mito trágico. (Nietzsche, 1952, p. 160)

Otra respuesta puede hallarse, a propósito del mito, en la coincidentia oppositorum, la coincidencia de los opuestos: el carácter polivalente de los mitos propicia que en muchos casos características contradictorias concurran en un mismo elemento, así, vida/muerte, luz/ sombra, dicha/tristeza.

Para algunos rétores, en cambio, los temas míticos comportan, ya de por sí, un carácter sublime, por sus rasgos sobrenaturales. Esto, precisamente, permite justificar que los monstruos estén asociados a altos valores literarios.

Por último, grosso modo, se encuentra la posición aristotélica, para la cual, el valor estético de los monstruos estaría en función de la tesis que se deseara probar. Adicionalmente, por su separación respecto del mundo natural, presentan un fuerte grado de atracción.

De esta manera, las diversas explicaciones al goce estético asociado al tema de los monstruos puede organizarse así:

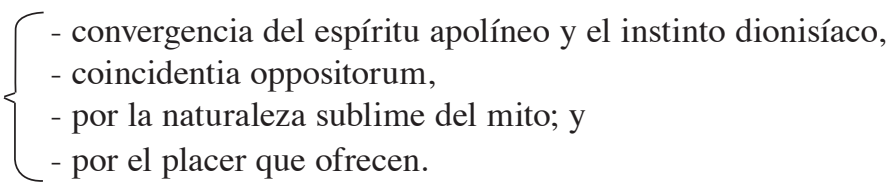

Cada una de estas tesis será desarrollada de una u otra forma en las siguientes páginas. 


\subsection{Los monstruos, síntesis del pensamiento apolíneo y el espíritu dionisíaco}

Desde un plano meramente estético, los monstruos parecen ser una instancia clara de operación del espíritu apolíneo y el instinto dionisíaco, en los términos planteados por Nietzsche en El origen de la tragedia. En pocos ámbitos del pensamiento antiguo resulta tan clara la presencia de ambos principios de composición, cuyas equivalencias se muestran en la siguiente tabla:

\begin{tabular}{|c|c|}
\hline Instinto dionisíaco & Espíritu apolíneo \\
\hline verdad & ilusión \\
\hline universalizante & principio de individuación \\
\hline estado orgiástico & estático \\
\hline delirio & calma \\
\hline inconsciente & razón \\
\hline escéptico & optimista \\
\hline brutalidad & equilibrio \\
\hline páthos & lógos \\
\hline libertad & ley \\
\hline destino & voluntad \\
\hline fuerza artística primitiva & fuerza artística moderna \\
\hline fuerza eterna & fuerza perecedera \\
\hline
\end{tabular}

Por esto, no es extraño que

A causa de su titanesco amor a la Humanidad, Prometeo tuvo que ser destrozado por el buitre; por su excesiva sabiduría, que le hizo adivinar el enigma de la esfinge, Edipo se vio arrastrado a un torbellino inextricable de monstruosos delitos: así es como el dios de Delfos interpretaba el pasado griego.

Del mismo modo, al griego apolíneo le parecía "titanesco" y "bárbaro" el estado emotivo provocado por el estado dionisíaco, y ello sin que pudiese engañarse respecto de la afinidad profunda que le acercaba a esos titanes vencidos y a esos héroes [...] ¡Y, no obstante, Apolo no pudo vivir sin Dioniso! Lo "titánico", lo "bárbaro" fue, en último extremo, una necesidad, una necesidad tan imperiosa como lo apolíneo. (Nietzsche, 1952, p. 41)

Efectivamente, pese al carácter binario de este sistema, en realidad ambas columnas interactúan incesantemente, al grado de que Dioniso llegará a hablar la lengua de Apolo, mientras que Apolo la de Dioniso.

Como síntesis se tiene aquello que Nietzsche ve en la epopeya:

Tan prodigioso es el poder del arte épico apolíneo, que transfigura a nuestros ojos las cosas más horribles, por ese goce que sentimos al contemplar la apariencia, la visión, por esa felicidad redentora que nace para nosotros de la forma exterior, de la apariencia. (Nietzsche, 1952, p. 87)

\section{La razón estriba en que}

[...] el arte avanza entonces como un dios salvador que trae el bálsamo saludable: él sólo tiene el poder de transmutar ese hastío de lo que hay de horrible y absurdo en la existencia, en imágenes que ayudan a soportar la vida. Estas imágenes son lo "sublime", en el que el arte doma y sojuzga a lo horrible, y lo "cómico", con el que el arte nos libra de la repulsión de lo absurdo. El coro de sátiros del ditirambo fue la salvación del arte griego; los accesos de desesperación que acabamos de referir se desvanecieron gracias al mundo intermediario de estos compañeros de Dioniso. (Nietzsche, 1952, pp. 60-61) 
En efecto,

[...] la cultura apolínea, que siempre tiene que derribar un imperio de titanes, vencer monstruos y triunfar con ayuda del poderoso espejismo de ilusiones agradables, del profundo horror del espectáculo del mundo y de la más exasperada sensibilidad para el sufrimiento [...] La "ingenuidad" homérica no debe ser comprendida sino como la completa victoria de la ilusión apolínea: una ilusión semejante a las sugeridas tan frecuentemente por la naturaleza para conseguir sus fines. (Nietzsche, 1952, p. 38)

Nuestra especie puede vencer a los monstruos, a la naturaleza, o, por lo menos, sobrevivirles.

Esto fue necesario, ya que

Para poder vivir fue preciso que los griegos, impulsados por la más imperiosa necesidad, creasen estos dioses; y podemos representarnos tal evolución por el espectáculo de la primitiva teogonía tiránica del espanto, transformándose bajo el impulso de este instinto de belleza apolínea y llegando a ser, por transiciones insensibles, la teogonía de los goces olímpicos, como las rosas que nacen de un zarzal espinoso (Nietzsche, 1952, p. 37)

\subsection{De monstruos, mitos y mímesis}

Miríadas de pensadores y lectores de Aristóteles han concebido la mímesis como imitación de la realidad.

Nietzsche no escapa a esta tendencia, aún cuando concibe que

[...] el arte no es solamente imitación de la realidad natural, sino un suplemento metafísico de la realidad natural, yuxtapuesto a la misma para contribuir a vencerla. El mito trágico, en cuanto parte integrante del arte, se utiliza también para suscitar esta transfiguración, que es el fin metafísico del arte en general (Nietzsche,1952, p. 159)

Sin embargo, el sintagma aristotélico es muy distinto a como se le ha entendido, específicamente él dice: $\tau \hat{\eta} \varsigma \pi \varrho \alpha ́ \xi \varepsilon \omega \nu$ o $\mu \hat{v} \theta o \varsigma \dot{\eta} \mu \dot{\mu} \mu \eta \sigma \iota \sigma$ (1992: 146, 1450a3-4), el mito es mímesis de acciones.

En realidad, es el anónimo autor de Sobre lo sublime quien establece como

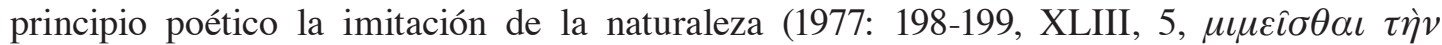

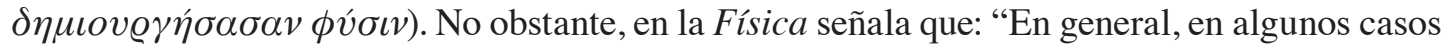
el arte completa lo que la naturaleza no puede llevar a término, en otros imita a la naturaleza" (Aristóteles, 1995, p. 199a13); pasaje que ciertamente no se refiere de manera directa a la labor de los poetas, sino, más bien, de los constructores.

Siempre en el tema de la imitación, Hermógenes, en Sobre las formas de estilo, considera que "la poesía es una imitación de todas las cosas" (1993, 293, 390).

Ahora bien, ¿cómo conciliar el carácter mimético de la poética con seres fabulosos como los monstruos?, máxime si la labor del poeta es hacer mitos (Aristóteles, 1992, 160, 1451b27-28).

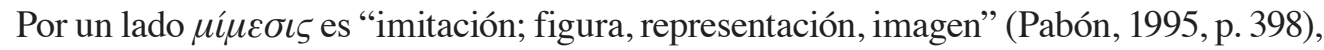
mientras que $\mu \hat{v} \theta o \varsigma$ significa

palabra, discurso, razón, dicho; discurso público; relato, comunicación, noticia, mensaje; conversación, plática; deliberación consigo mismo, reflexión, pensamiento, opinión, resolución, proyecto, designio, plan; consejo, propuesta, mandato, encargo; rumor, hablilla; relato imaginado, invención, leyenda, mito, fábula, cuento; objeto de la conversación, asunto, historia (Pabón, 1995, p. 403)

Si bien el vocablo $\mu \hat{v} \theta o \varsigma$ es sumamente polisémico en griego, en el contexto de lo monstruoso esta propiedad se reduce hasta coincidir prácticamente con el uso contemporáneo del término mito, ya que los monstruos griegos encuentran su lugar de acción en ellos. 
Por lo tanto, puede hablarse de una verdadera paradoja entre estos dos principios poéticos, entre la mímesis y el imperativo mítico del poeta. Sin embargo, esta contradicción obedece a un tipo particular de lectura, tal y como se mostrará a continuación.

Aristóteles define el mito de manera muy semejante a la tragedia: el mito es una imitación de acciones (para la tragedia, véase 1992, 144, 1449b14, para el mito 146, 1450a3-4), esta última en griego se expresa:

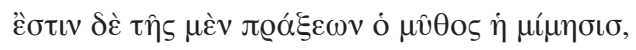

el mito es imitación de acciones (traducción del autor).

Esta concepción ha sido severamente criticada a lo largo de los siglos, ya que parece someter la labor del poeta a la de un servil esclavo de la realidad. Sin embargo, surge la duda acerca de si Aristóteles creía o no que la creación poética era una esclava, una sierva de la realidad. Ciertamente, que no. Por un lado, es poco creíble que el pensador de Estagira creyera, luego de la crítica presocrática, socrática y platónica en la supuesta realidad de los mitos de su tiempo. Ahora bien, ¿cómo es posible conciliar esta premisa con esta concepción del mito que lo vincula a la imitación?

A este respecto, conviene proceder tal y como lo habría hecho el propio Aristóteles y distinguir, primero que todo, los diversos sentidos de la imitación, o más específicamente, del sintagma imitación de acciones. Tanto respecto de la tragedia como del mito, se emplea la misma voz griega, $\pi \varrho \hat{\alpha} \xi \iota \sigma$; he aquí algunas de sus acepciones:

acción, hecho, ocupación, asunto, negocio, cosa importante, ejecución, realización, objeto; modo de obrar, obligación, tarea, empresa, negociación; circunstancia, situación, coyuntura; dificultad, embarazo, molestia, perplejidad, situación desagradable o difícil, embrollo, enredo, intriga, traición [...]; la cosa pública; los negocios del Estado, el gobierno, el poder... (495-496)

Pese a la amplitud polisémica de este significante, para lo efectos de esta investigación, es posible encontrar un común denominador a sus diversos sentidos: alude a algo fuera del poeta, a lo que por lo general conocemos como realidad.

Ahora bien, estas acciones, estos eventos por imitar, ofrecen, por lo menos, tres facetas principales que pueden ser objeto de imitación:

a. por un lado, se puede imitar la acción propiamente dicha, es decir, la sucesión de eventos;

b. por otro, se pueden imitar sus propiedades generales; o bien

c. se pueden imitar sus propiedades óntico-epistémicas.

La mayor parte de los estudios se concentran en los dos primeros sentidos de la imitación, de ahí la crítica al servilismo poético; sin embargo, parecen contradecir lo que tanto Aristóteles como sus contemporáneos filosóficos podían creer sobre el mito.

Deviene por lo tanto la conveniencia de explorar el tercer sentido: la narración explota las características óntico-epistémicas de las acciones. Estas características consisten específicamente en su realidad y posibilidad. Las acciones míticas deben verse y ser aprehendidas como reales.

Tal concepción no solo es consistente con los dos postulados aristotélicos sobre la creación mítico-poética, sino que es compatible con la libertad ejercida por los poetas en sus composiciones. 
Así, la poética debe construir un mundo que parezca real, he aquí su carácter mimético. Lo que imita es la "apariencia" de realidad que tiene el mundo real.

La narración debe imitar a tal punto la realidad que parezca real, lo cual es consistente en todo sentido con el principio de verosimilitud.

En síntesis: el mito debe ser tan real como la realidad misma.

Ahora bien, ¿es esta tesis compatible con el pensamiento aristotélico? La respuesta es un rotundo sí.

Al comparar el quehacer del historiador con el del poeta, Aristóteles sostiene que

\begin{abstract}
[...] el historiador y el poeta no se diferencian por decir las cosas en verso o en prosa [...]; la diferencia está en que uno dice lo que ha sucedido, y el otro, lo que podría suceder. Por esto también la poesía es más filosófica y elevada que la historia; pues la poesía dice más bien lo general, y la historia, lo particular. Es general a qué tipo de hombres les ocurre decir o hacer tales o cuales cosas verosímil o necesariamente, que es a lo que tiende la poesía $(1992,158,1451 b 1-7)$
\end{abstract}

Esta comparación muestra una primera escisión entre la realidad como tal, objeto de la historia, y la creación poética: ambas construcciones literarias no coinciden.

Partiendo de la labor de los cómicos, quienes también son poetas, de inmediato se ejemplifica esta situación:

Pues bien, en cuanto a la comedia, esto resulta claro; en efecto, después de componer la fábula verosímilmente, asignan a cada personaje un nombre cualquiera, y no componen sus obras, como los poetas yámbicos, en torno a individuos particulares (1992, 159, 1451b12-15)

El carácter ficcional de la creación mítica es ya a estas alturas evidente. Sin embargo, conviene considerar una ligera réplica: en 1451b16-17 Aristóteles señala que las tragedias tratan de nombres que han existido.

Empero, tal rasgo obedece a que esto dota de mayor verosimilitud a la obra, tal y como el propio autor reconoce. En todo caso, de inmediato agrega:

Sin embargo, también hay tragedias en que son uno o dos los nombres conocidos, y los demás, ficticios; y en algunas ninguno, por ejemplo, en la Flor de Agatón, pues aquí tanto los hechos como los nombres son ficticios, y no por eso agrada menos.

De suerte que no se ha de buscar a toda costa atenerse a las fábulas tradicionales sobre las que versan las tragedias. Sería, en efecto, ridículo pretender esto, ya que también los hechos conocidos son conocidos de pocos, y sin embargo deleitan a todos (1992: 159-160, 1451b19-26)

Es en el contexto de las citas precedentes que Aristóteles procede a formular la siguiente conclusión:

De esto resulta claro que el poeta debe ser artífice de fábulas más que de versos, ya que es poeta por la imitación, e imita las acciones. Y si en algún caso trata cosas sucedidas, no es menos poeta; pues nada impide que algunos sucesos sean tales que se ajusten a lo verosímil y a lo posible, que es el sentido en que los trata el poeta (1992: 160, 1451b27-32)

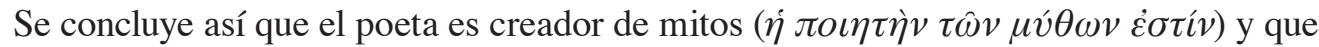

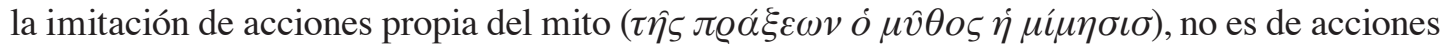
necesariamente sucedidas. Esto se comprende al entender que la imitación es, tal y como supra se enunció, de la "apariencia" de realidad que tiene el mundo real.

La mímesis de las acciones no es un calco de la realidad, al menos, como fue entendido por muchos estudiosos a lo largo de los siglos. Es solo un presupuesto para cumplir lo que muchos denominan como pacto ficcional de la literatura.

Además, ha quedado demostrado cómo Aristóteles mismo reconoce la libertad del poeta para sus composiciones. 


\section{3 ¿Qué son los monstruos?}

En la Física y la Reproducción de los animales, Aristóteles trata el tema de los monstruos. Ambas obras examinan su origen, ya que se les considera generados contra la

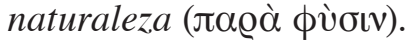

La Física apunta que

[...] cuando se genera algo contrario a la naturaleza no decimos que se ha generado fortuitamente, sino por casualidad. Pero hay también esta diferencia: la causa de un resultado casual es externa, mientras que en la generación contra naturaleza es interna (Aristóteles, 1995, 197b34-36)

Más adelante agrega:

[...] es evidente que estos errores también se pueden producir en las cosas naturales. Pues si hay cosas artificiales en la que lo producido se ha hecho correctamente con vistas a un fin, y también otras hechas erróneamente cuando el fin que se pretendía no se ha alcanzado, lo mismo puede suceder en las cosas naturales, y los monstruos serían errores de las cosas que son para un fin. Esto tiene que haber ocurrido en la constitución inicial de los terneros de rostro humanos, ya que si fueron incapaces de llegar a su término o fin fue por defecto de algún principio, como ocurre todavía hoy en ciertos casos por defecto del semen (Aristóteles, 1995, p. 199a35-199-8)

Conviene recordar aquí que en la teoría aristotélica de las causas, una de ellas es la causa final: todo posee un fin para el cual fue hecho, es decir, para lo que fue hecho, lo cual está estrechamente asociado a la forma, en vez de la materia (Aristóteles, 1995, p. 199a33).

También en relación con la causa final, en la Reproducción de los animales agrega:

En cuanto al monstruo, no es necesario en lo que respecta al para qué, o sea, la causa final, pero es necesario por accidente, ya que ahí de alguna manera debe tener su origen (Aristóteles, 1994, 249, 767b13-16)

Esto se comprende pues el monstruo no satisface su causa final, ya que no se adecua a ella por cuanto su forma es inapropiada. Sin embargo, es precisamente su forma la que lo presenta como monstruoso.

En esta última obra, Aristóteles pasa revista a un amplio número de mutaciones y deformaciones en los animales; sin embargo, para efectos del presente estudio, la visión aristotélica es muy reducida, ya que se limita a fenómenos biológicos, mientras que aquí nos ocupa la perspectiva mítica. Empero, pueden rescatarse algunas de sus apreciaciones sobre su noción de monstruo:

[...] lo monstruoso consiste en la carencia o exceso de algo. Y es que la monstruosidad entra dentro de las cosas que van contra la naturaleza, pero no contra la naturaleza en su totalidad, sino contra lo que es la norma: pues en lo que concierne a la naturaleza eterna y por necesidad, nada ocurre contrario a ella; en cambio, sí ocurre en las cosas que por lo general son de una determinada manera, pero que pueden también serlo de otra; porque incluso en esos casos que van contra este orden concreto, sin embargo, nunca es la azar, y parece menos monstruosidad porque incluso lo que va contra la naturaleza está en cierto modo de acuerdo con la naturaleza, cuando la naturaleza formal no prevalece sobre la naturaleza material. Por eso tales casos no se llaman monstruosos, ni tampoco en las demás situaciones donde se da algo de forma habitual, como en los frutos. En efecto, hay cierta vid que algunos llaman "ahumada", que, si produce uvas negras, no la consideran una monstruosidad porque muchas veces acostumbra a hacerlo. La razón es que por naturaleza está entre la vida blanca y la negra, de modo que la alteración no es desde algo muy distante, ni parece contra natura: pues no es un cambio a otra naturaleza (Aristóteles, 1992, 259, 770b9-24)

La monstruosidad, en primera instancia, atiende a la forma. Consiste, ya en una presencia, ya en una carencia, de carácter excesiva. Esta última incluso puede obedecer a una mutilación, “pues también la monstruosidad es una especie de mutilación” (1992, 256, 769b30-31). 


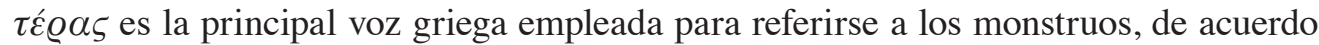
con Pabón significa "signo, presagio, portento, prodigio, señal espantosa enviada por los dioses; monstruo, animal monstruoso; cosa extraordinaria, prodigiosa, monstruosa" (1995, p. 580).

A su familia léxica pertenece el verbo $\tau \varepsilon \varrho \alpha ́ \xi \omega$, "interpretar por signos, por presagios; pronosticar, profetizar” (Sebastián-Yarza, 1964, p. 1367), por cuanto en el pensamiento antiguo la monstruosidad se interpretaba como un signo, una señal de los dioses o del universo.

De esta palabra proviene el prefijo tera- que en español representa un billón de veces.

El vocablo $\theta \alpha \hat{v} \mu \alpha$ también es empleado por diversos autores griegos en este tema, ya que significa "maravilla, cosa, objeto $o$ aparición digna de admirarse (...); en pl. jugadas $o$ suertes extraordinarias, prestigios; admiración, sorpresa, asombre” (Pabón, 1995, p. 292).

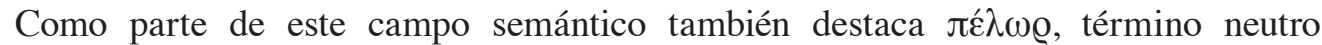
indeclinable que significa "monstruo, prodigio" (Pabón, 1995, p. 466), del cual deriva el

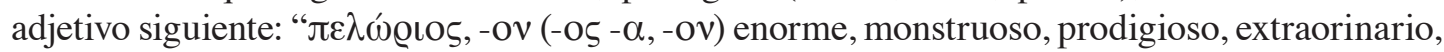
espantoso, horrible" (ibid).

Dicho adjetivo ofrece uno de los usos más antiguos registrados, ya que Hesíodo lo emplea en la Teogonía para referirse a Gea, la Tierra.

Por último, también existe en griego el término $x v \omega ́ \delta \alpha \lambda o v$, el cual significa animal salvaje, especialmente jabalí, león; monstruo, dragón (Pabón, 1995, p. 350).

Aunque las referencias aristotélicas apuntan primordialmente a los aspectos físicos de la monstruosidad, esta puede hallarse también en el ámbito moral o bien en conductas o eventos naturales.

\footnotetext{
[...] también, por qué causa el ser que nace unas veces es un ser humano pero que no se parece a ninguno de sus antepasados, y otras, llega a tal resultado que ni parece un hombre sino sólo un animal: lo que precisamente se 1laman monstruos (Aristóteles, 1992, 255, 769b7-11)
}

En nuestra especie, parte de la monstruosidad física se produce al aproximar al individuo al reino de los animales (aunque ya de por sí pertenece a él).

Algunas malformaciones no se asocian a la monstruosidad, pues no comportan un cambio de naturaleza; incluso, los híbridos, producto de la cópula de animales de distinta especie (como el mulo y ciertas mezclas entre perro, zorros y lobos, por ejemplo), no aparecen expresamente calificados de monstruos (Aristóteles, 1992, 176-177, 746a30-746b11).

Respecto del concepto de normalidad, más adelante se tiene que "Si en algún caso se produjera más materia, entonces nacerían gemelos. Por eso, incluso tales seres parecen más bien una monstruosidad porque se originan en contra de lo general y acostumbrado" (Aristóteles, 1992, 264, 772a36-38).

De manera que el concepto de monstruo devendría en función de una especie de valor estadístico.

San Isidoro de Sevilla trata también el tema de los monstruos, cuyas ideas son tributarias de las de Aristóteles; sin embargo, algunas de sus apreciaciones enriquecen sobremanera la aproximación a este tema. Así, por ejemplo, indica:

\footnotetext{
Varrón dice que portentos son las cosas que parecen nacer en contra de la ley de la naturaleza. En realidad, no acontecen contra la naturaleza, puesto que suceden por voluntad divina, y voluntad del Creador es la naturaleza de todo lo creado. De ahí que incluso los gentiles denominen a Dios una veces Naturaleza, otras simplemente Dios. En consecuencia, el portento no se realiza en contra de la naturaleza, sino en contra de la naturaleza conocida (Isidoro de Sevilla, 2009, p. 879, XI, 3, 1-2)
} 
Sobre su etimología, San Isidoro señala que:

Y se conocen con el nombre de portentos, ostentos, monstruos y prodigios, porque anuncian (portendere), manifiestan (ostendere), muestra (monstrare) y predicen (praedicare) algo futuro. En efecto, explican que "portento" deriva de portendere, es decir, anunciar de antemano. Los "ostentos" porque parecen manifestar algo que va a ocurrir. Los "prodigios", porque "dicen previamente" (porro dicere), es decir, predicen lo que va a suceder. Por su parte, monstra deriva su nombre de monitus, porque se "muestran" para indicar algo, o porque "muestran" al punto qué significado tiene una cosa. Y éste es su significado propio, que se ha visto, no obstante, corrompido por el abuso que de esta palabra han hecho los escritores (Isidoro de Sevilla, 2009, p. 879, XI, 3, 2-3)

La etimología isidoriana en este caso es correcta, así lo confirman Ernout y Meillet en su Dictionnaire Étymologique de la Langue Latine:

mōnstrum, -ī n.: ut Aelius Stilo interpretatus, a monendo dictum est, uelut monestrum. Item Sinnius Capito, quod monstret futurum, et moneat uoluntatem deorum, Fest. 122, 8. Terme du vocabulaire religieux, "prodige qui avertit de la volonté des dieux"; par suite "objet ou être de caractère surnaturel", "monstre": monstra dicuntur naturae modum egredientia, ut serpens cum pedibus, auis cum quattuor alis, homo duobus capitibus, iecur cum distabuit in coquendo, F. 146, 32, et par extension, dans la langue familière, mōnstrum mulieris "monstre de femme", Plt., Poe. 273. M. L. 5665 a (Ernout y Meillet, 1967, p. 413)

Por su parte, ostentum pertenece al lenguaje augural en el que designa un presagio (ibid: 470). En un sentido semejante, portentum

[...] présage révélé par quelque phénomène étrage ou contraire aux lois naturelles; de là "chose merveilleuse, monstruosité, monstre" (même développement que dans mōnstrum); portentōsus; portentifer, -ficus, -loquium. Ancien, usuel et classique. Une distinction entre ostentum, portentum, mōnstrum est entée par Fest. 284, 4: portenta existimarunt quidam grauia esse, ostenta bona: alii portenta quaedam bona, ostenta quaedam tristia appellari. Portenta, quae quid porro tendatur, indicent: ostenta, quae tantum modo ostendant; monstra <quae> praecipiant quoque remedia (ibid: 524)

Tanto en griego como en latín, las voces asociadas a lo monstruoso poseen rasgos deícticos, pero, además, comunicativos: se consideran transmisores de un mensaje.

La sección 3 del libro XI de las Etymologiarum, está dedicada a los portentos. Tiene la particularidad de consagrar varias reflexiones a los monstruos míticos desde una perspectiva evidentemente evemerista. Por ejemplo,

\footnotetext{
Lo mismo cabe decir de las Gorgonas, meretrices cuyos cabellos eran serpientes y que transformaban en piedra a quienes las miraban; estaban dotadas de un solo ojo, que era común a todas ellas. En realidad, se trataba de tres hermanas de una única extraordinaria hermosura, un único ojo, diríamos, que de tal manera dejaban admirados a quienes las contemplaban, que uno podía pensar que se quedaban "convertidos en piedra". A las sirenas, que eran tres, se las imagina con un cuerpo mitad de doncella, mitad de pájaro, dotadas de alas y de uñas; una de ellas cantaba con su voz, otra con una flauta, ya la tercera con la lira; con su canto atraían a los navegantes fascinados, que eran arrastrados al naufragio. Pero lo cierto es que fueron unas meretrices que llevaban a la ruina a quienes pasaban, y éstos se veían después en la necesidad de simular que habían naufragado. Se dice que tenían alas y uñas, porque el amor vuela y causa heridas; y que vivían en las olas, precisamente porque las olas crearon a Venus (Isidoro de Sevilla, 2009, p. 885, XI, 3, 29-31)
}

Una racionalización del mito tiene igualmente lugar respecto de Escila, Cérbero, Hidra, Quimera, Centauro, Minotauro...

San Isidoro, en cambio, parece reconocer cierto grado de realidad a temas como las metamorfosis y ciertos grupos de seres. Sobre las transmutaciones de hombres en bestias, Isidoro parece reconocer la existencia de encantamientos y hierbas que lo hacen posible, a propósito de las acciones de los delincuentes para alcanzar su cometido (al respecto, puede verse 1995, 887, XI, 4). 
En cuanto a algunos grupos de entidades apunta: "Del mismo modo que en cada pueblo aparecen algunos hombres monstruosos, así también dentro del conjunto del género humano existen algunos pueblos de seres monstruosos, como los gigantes, los cynocéfalos, los cíclopes y otros más" (Isidoro de Sevilla, 1995, 881, XI, 3, 12).

\subsection{Retórica y monstruos}

La construcción retórica de la monstruosidad tiene lugar mediante la lógica de la amplificación: se amplifican ya sean defectos, vicios, extremidades, partes corporales...

Uno de los planteamientos procede del anónimo autor del Sobre lo sublime para quien lo monstruoso no comporta un menoscabo a la sublimidad, muy por el contrario, pertenece a su espacio natural.

Pareciera que se erige una flagrante contradicción, ya que

la armonía no es solo un medio natural de que el hombre dispone para persuadir y deleitar, sino que es, además, un maravilloso instrumento para alcanzar la sublimidad y el patetismo (Sobre lo sublime, 1977, p. 187, XXXIX, 1);

y nada más ajeno a lo armónico que lo monstruoso.

Empero, esta armonía se predica de la obra artística, en particular la literaria, no del mito:

en arte admiramos la corrección, en la naturaleza la grandiosidad; y la elocuencia humana es un don de la naturaleza. En escultura, lo que se busca es la semejanza con el modelo humano, en literatura, como dije antes, lo sobrehumano (Sobre lo sublime, 1977, p. 181, XXXVI, 3)

Ciertamente, el universo de los monstruos pertenece a este campo de lo sobrehumano, de lo sobrenatural, por lo que es la materia apropiada para alcanzar lo sublime, ya que "es lo extraordinario lo que suscita su admiración” (Sobre lo sublime, 1977, p. 179, XXXV, 5). Por esto, la presencia de seres monstruosos no afecta por sí mismo la sublimidad del discurso, por el contrario, la propicia.

Aunque en esta obra no se plantee directamente una retórica de los monstruos antiguos (sin embargo, se mencionan el Cíclope y la transformación en cerdos de los hombres de Odiseo, (Sobre lo sublime, 1977, pp. 03-105, IX, 14)), sí se tratan temas como el terror, el miedo y las catástrofes sin causar mella al espíritu sublime: "Es el mismo estilo, creo yo, con que el Poeta, al describir una tempestad, sabe seleccionar, de entre los detalles concretos, los más aterradores" (Sobre lo sublime, 1977, p. 107, X, 3).

Por esto, es posible encontrar expresiones como las siguientes, a propósito de algunas escenas de la Ilíada:

¿No te da la impresión, amigo mío, de estar contemplando la escena?: la tierra entreabriéndose hasta sus raíces, el Tártaro mismo descubriendo sus simas, el universo entero trastocado, desgarrado; todos sus componentes cielo, infierno, mortales, inmortales, tomando parte al mismo tiempo en esa batalla, en ese trance?

Mas cuadros como ése son terribles, y sólo a condición de tomarlos por expresiones alegóricas no resultan absolutamente impíos y carentes de todo sentido de la conveniencia. Y es que cuando describe las heridas de los dioses, sus querellas, sus venganzas, sus lágrimas, sus encarcelamientos, sus múltiples pasiones, Homero, a mi entender, pone en juego todos sus resortes para convertir en dioses a los hombres que participaron en el sitio de Troya, y a los dioses en hombres. Pero nosotros, los seres humanos, todavía disponemos, en el infortunio, de un puerto para nuestras desgracias: la muerte. Mas, en el caso de los dioses, no es su naturaleza, sino su miseria, lo que Homero ha hecho inmortal (Sobre lo sublime, 1977, pp. 97-99, VIII, 6-7) 
Uno de esos resortes para engrandecer a los héroes es precisamente el enfrentarse a los portentosos monstruos míticos.

A semejanza del anónimo autor del Sobre lo sublime, en el siglo II de nuestra era, Hermógenes vincula lo monstruoso, a través de lo mítico, a la solemnidad y grandeza de estilo, a la vez que a la dulzura, esta última, como parte del carácter de la composición.

Para este autor,

Son sobre todo propios de la poesía todos los pensamientos referidos a mitos, como los relatos sobre Crono y los titanes, y los gigantes y el propio Zeus y los demás dioses, que están descritos como si tuvieran sentimientos humanos: cómo nacieron y qué hazañas realizaron o realizan entre ellos y entre los hombres, sus amores, sus guerras, sus amistades, sus proles, sus crianzas y temas similares. Además de estos relatos, los portentos que se narran sobre hombres o ciertos animales; por ejemplo, cómo Cadmo se convirtió de hombre en serpiente, y Alción en pájaro, y los relatos acerca de ruiseñores o golondrinas. Pertenecen a esta clase también la conversión de hombres en mujeres, como Tiresias, o de mujeres en hombres, como Ceneo. Es similar también la descripción de hombres alados, o su nacimiento y, en general, de ciertos animales híbridos o monstruosos, como Pegasos, Gorgonas, centauros, sirenas, tritones, lestrígones, cíclopes, Perseo y otros similares. Poseen también carácter mítico y poético los hechos que sobrepasan la naturaleza humana, prodigios que los poetas relatan como hechos reales y dignos de crédito, como las proporciones del salto de Aquiles, y el peso de la piedra que Ayax o Héctor lanzaban con facilidad, la talla tan grande que tenían y, en general, las ficciones poéticas de este calibre. También, el decir que los seres inanimados ayudan a los dioses con algún tipo de inteligencia, por ejemplo: "Por su propia voluntad se abrieron rechinando las puertas del cielo", "Bajo ellos hacía crecer la divina tierra" y, en general, la narración de prodigios imposibles o increíbles. No obstante, el pasaje: "Los monstruos lo criaron cabe él", y otros similares, son poéticos y agradables, como hemos dicho en el capítulo dedicado a la Dulzura, pero son menos prodigiosos, a menos que se diga que es extremadamente mítico y poético que los caballos u otros animales emitan voces humanas (Hermógenes, 1993, pp. 295296, 391-392)

Este tipo de composiciones precisa:

a. invocar a las musas, Apolo o a algún otro dios.

b. atribuir al dios la narración.

c. ser detallista, para alcanzar simplicidad y poética.

d. adecuar el metro a la expresión de la narración y los personajes.

e. aprovechar las cesuras.

En Sobre las formas de estilo, Hermógenes plantea que el carácter ficcional de los mitos los vincula más con la poesía que con la prosa, esta última, de la que no necesariamente se ve excluida: "Pero, puesto que en el discurso político los relatos míticos producen languidez, el Orador, mediante los componentes propios de la Viveza, ha atenuado aquí la excesiva languidez segmentando la materia” (Hermógenes, 1993, pp. 229-330).

Los temas míticos producen dulzura y placer, efectos que disminuyen conforme lo narrado se estima como un hecho real (Hermógenes, 1993, pp. 229-331).

Estos temas también poseen rasgos solemnes, en primer lugar, los referidos a los dioses; luego, a las causas de los fenómenos naturales; seguidamente, las materias divinas (como la inmortalidad del alma, la justicia, la templanza...); las relaciones entre conceptos y las alegorías:

También los tratamientos alegóricos, si se mantienen, hacen el estilo solemne, como en "El gran caudillo del cielo, Zeus, avanza conduciendo su carro alado", etcétera. Quiero decir que esto es así, si voluntariamente no se habla de forma alegórica mediante términos corrientes y vulgares, pues en ese caso ya no se convierte el estilo en solemne, sino en propio de otro tipo de pensamiento, y casi en vulgar (Hermógenes, 1993, pp. 131-132, 246) 
Tales asociaciones permiten identificar la presencia de un componente cultural: los griegos asociaron lo mítico y, por ende, lo monstruoso, a lo solemne, dulce y grandioso.

Se dirá que los monstruos no deben identificarse con lo mítico. Empero, en Grecia, esto no fue así, tal y como las diversas citas ofrecidas constatan.

Para Aristóteles, en cambio, la atracción que ejerce lo monstruoso puede originarse en tres causas principales:
a. representa un cambio,
b. suscita admiración y
c. constituye una imitación.

Cada uno de estos tres factores suscita placer, deseo, atracción.
Y cambiar también causa placer, pues el cambio es conforme con el sentido de la naturaleza, ya que <la repetición $>$ siempre $<$ de $>$ lo mismo provoca un exceso del modo de ser establecido. De donde se ha dicho: Dulce es el cambio de todas las cosas (270, I, 11.4, 1371a26-28)

Seguidamente añade,

Igualmente, el aprender y el admirar son la mayoría de las veces placenteros, puesto que, por una parte, en el admirar está contenido el deseo de aprender -de modo que lo admirable es deseable-y, por otra parte, en el aprender se da un estado <que es> conforme con el sentido de la naturaleza (271, I, 11.4, 1371a31-34)

Por último, concluye

\begin{abstract}
Y como aprender es placentero, lo mismo que admirar, resulta necesario que también lo sea lo que posee estas mismas cualidades: por ejemplo, lo que constituye una imitación, como la escritura, la escultura, la poesía, y todo lo que está bien imitado, incluso en el caso de que el <objeto > de la imitación no fuese placentero; porque no es con éste con lo que se disfruta, sino que hay más bien un razonamiento sobre que esto es aquello, de suerte que termina por aprenderse algo. Igualmente <son placenteras $>$ las aventuras y el salvarse por poco de los peligros, por cuanto estas cosas son todas ellas admirables (271, I, 11.4, 1371b5-11, el subrayado es nuestro)
\end{abstract}

Una idea semejante se encuentra en su Poética, cuando expresa:

[...] y también (es connatural) el que todos disfruten con las obras de imitación. Y es prueba de esto lo que sucede en la práctica; pues hay seres cuyo aspecto real nos molesta, pero nos gusta ver su imagen ejecutada con la mayor fidelidad posible, por ejemplo, figuras de los animales más repugnantes y de cadáveres. Y también es causa de esto que aprender agrada muchísimo no sólo a los filósofos, sino igualmente a los demás, aunque lo comparten escasamente. Por eso, en efecto, disfrutan viendo las imágenes, pues sucede que, al contemplarla, aprenden y deducen qué es la cada cosa, por ejemplo, que éste es aquél; pues, si uno no ha visto antes al retratado, no producirá placer como imitación, sino por la ejecución, o por el color o por alguna causa semejante (Aristóteles, 1992, p. 136, 1448b8-19)

Respecto de los monstruos míticos, hay claras limitaciones a este respecto, por cuanto no existe un referente físico con el cual se pueda comparar la caracterización. Sin embargo, tal y como apunta el final de la cita, el placer se produce aun así debido al conocimiento que se adquiere, aunado a otros factores y elementos de la composición, ya plástica, ya literaria: he aquí la síntesis y racionalización de la estética-retórica de lo monstruoso.

El operador fundamental en Aristóteles es la amplificación, la más apropiada a los discursos epidícticos (253, I, 9.6, 1368a26).

Respecto de su particularidad, se trata de un relato con rasgos de elogio, ya que 
el elogio es un discurso que pone ante los ojos la grandeza de una virtud. Conviene, por lo tanto, presentar las acciones como propias de tal virtud. A su vez, el encomio se refiere a las obras (si bien, para la persuasión, sirven también las circunstancias que las rodean, como, por ejemplo, la nobleza y la educación, ya que es efectivamente probable que sean buenos los hijos de buenos padres o que se comporten de una determinada manera los que han sido criados así). Y, por eso, hacemos el encomio de quienes han realizado <alguna acción>. Las obras, por su parte, son signos de los modos de ser; por lo que incluso podríamos elogiar al que ninguna ha hecho, si estuviéramos persuadidos de que es capaz $<$ de hacerla> (249-250, I, 9.5, 1367b27-34)

\subsection{Los monstruos y las retóricas especiales}

Por su pertenencia al ámbito mítico en la antigüedad, el tratamiento de los monstruos pertenece a las retóricas especiales, entendidas como aquéllas que establecen los principios retóricos para un género o subgénero particular.

Aunque no se encuentre en la Grecia antigua un tratado concreto sobre los monstruos, sí ha sido posible identificar algunos principios compositivos en las retóricas generales. En las especiales, es en el ámbito del discurso epidíctico en el que se pueden hallar algunas reglas:

Pues bien, la clase del vituperio es indivisible; una alabanza, en cambio, lo es o en honor de dioses, o de seres mortales. Cuando en honor de dioses, las llamamos "himnos", y los clasificamos, a su vez, según el dios. Así, a los de Apolo los denominamos "peanes" e "hiporquemas"; a los de Dioniso, "ditirambos" y "iobacos" y con cuantos nombres parecidos se aplican a los de Dioniso; a los de Afrodita, "eróticos"; a los en honor de los demás dioses, o bien, por su denominación genérica, los llamamos "himnos" o, más específicament, "en honor de Zeus" por ejemplo (Menandro el Rétor, 1996, p. 88, 331, 18-332, 3)

Menandro el Rétor divide el género epidíctico en función del objeto así:

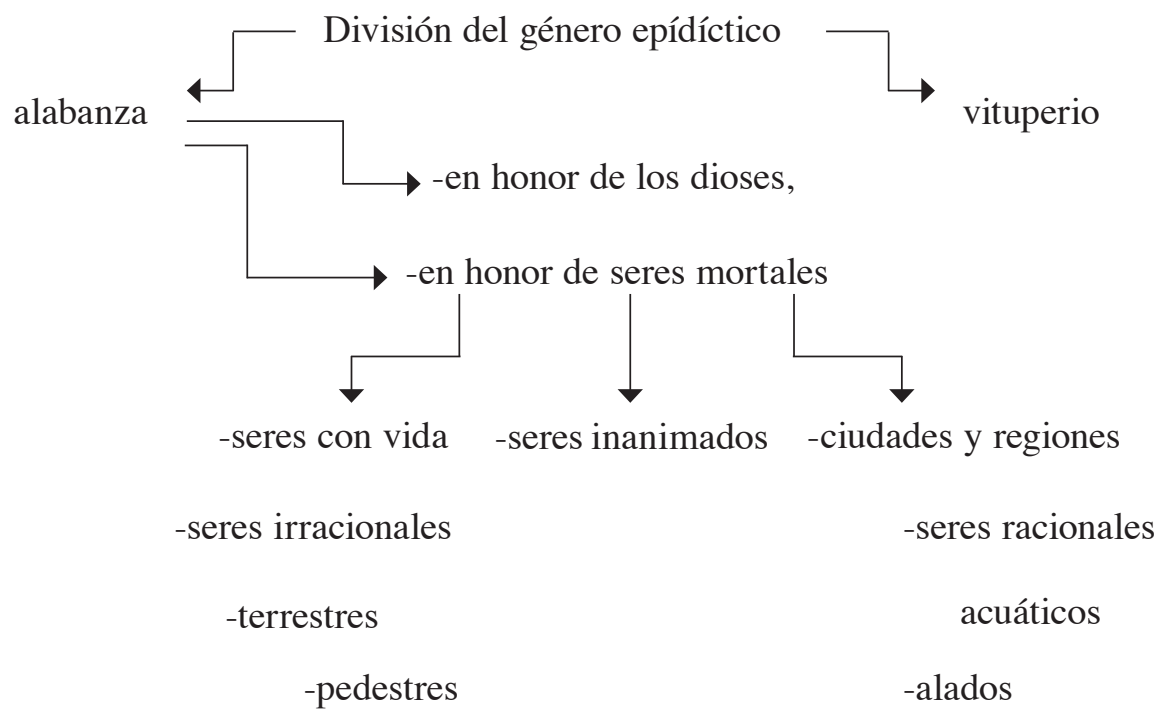

En el mundo antiguo, los monstruos intervinieron en cada uno de estos ámbitos, por lo que su presencia discursiva estaba justificada en el contexto de acuerdo con el tipo de discurso.

Aunque para Menandro el Rétor su empleo podía tener lugar tanto en prosa como en poesía, sin embargo, 
[...] a prosistas y oradores se les impone una única y sencilla limitación: a la poesía su relación con lo divino le confiere mayor licencia para ello, mientras que la prosa parte de unos presupuestos principalmente referidos al hombre (Menandro el Rétor, 1996, p. 93, 334, 1-5)

Inteligencia en la que parece haber unanimidad entre los tratadistas: la poética es el espacio más adecuado para su tratamiento.

Respecto de los himnos, se establece una clasificación que los divide en invocatorios, de despedida, científicos, míticos, genealógicos, ficticios, precatorios, deprecatorios y mixtos.

Debido a la extensión del tratamiento, solo se hará una breve referencia a dos de las propuestas: los himnos ficticios y la alabanza de una ciudad por su origen.

Los ficticios despiertan cierto interés en razón de constituir un espacio válido para la creatividad y originalidad del poeta, lo que Menandro el Rétor denomina licencia (1996, 104, 341,11 ), lo que permite precisamente que sean muy productivos y muestren gran inventiva.

Su primera recomendación consiste en que "[...] no deben referirse a los dioses más celebrados y cuyos nacimientos y poderes son de sobra conocidos, sino, a lo sumo, de los dioses más desconocidos y de démones" (Menandro el Rétor, 1996, 104, 341, 1-5).

Ahora bien,

\begin{abstract}
Hay que tener cuidado primero de inventar no de manera incongruente, sino con coherencia; y eso se puede conseguir, si la invención se configura a partir de ellos y no queda desligada; después, de no hacer la invención con mal gusto, sino de manera atractiva y decorosa, como lo de las Musas, hijas de la Memoria, o cualquier cosa así -y es que algunos incluso son desagradables de oír, como lo de que Atenea salió de la cabeza de Zeus; pues eso no es correcto, a no ser que se haya dicho mediante alegoría y con relación a alguna otra cosa; de otra manera, se hace una invención de mal gusto-; después de basar las pruebas de lo que inventemos en algo verdadero, como nosotros hemos hecho, y con frecuencia Homero. Además, hay que procurar que los himnos ficticios sean coherentes consigo mismos y no conlleven contradicciones o discrepancias, como en el mito aquel en que Zeus nació antes que todos los seres y es padre de toda divinidad, y se casó con Temis, que era antaño mujer de Crono. Pues si era anterior a todo, también anterior a Temis, pero si Temis era anterior a Zeus, no sería él anterior a todo (Menandro el Rétor, 1996, 105-106, 341, 18-142, 4)
\end{abstract}

De la cita anterior, se desprenden los siguientes principios compositivos:

- el mito ha de ser coherente,

- placentero,

- decoroso (salvo alegoría), y

- fundamentado en pruebas.

En cuanto a su extensión, han de ser moderados y su elaboración no ha de ser excesiva.

Sobre el estilo, estará en función del tema: los de carácter humano han de ser más sencillos y graciosos; los de orden divino, más majestuosos (Menandro el Rétor, 1996, pp. 14-18, 106, 342).

La alabanza de una ciudad por su origen merece ser mencionada ya que el segundo tópico a desarrollar en este tipo de discursos atiende al fundador: así, si fue un dios, el discurso debe ser solemne; si un semidiós o un héroe, glorioso, aunque menos solemne; si un hombre, glorioso para generales o reyes; mientras que modesto y sin esplendor para los particulares (Menandro el Rétor, 1996, pp. 123-124, 353, 5-18).

Otro de los tópicos, de particular interés para este trabajo, lo constituye el de las causas de la fundación de la ciudad: 
Pues bien, causas de fundación de ciudades las hay divinas, heroicas o humanas; a su vez, o en medio de una gran alegría, o por alguna circunstancia dolorosa; y, a su vez, según los capítulos llamados "de finalidad", tales como justicia, hermosura, conveniencia o necesidad. Es necesario poner ejemplos de eso. Causa divina es, por ejemplo, la de Rodas o Delos. De Rodas dirás: "al repartirse Zeus, Posidón y Hades el mundo, no dejaron parte alguna para Helio, y, al darse cuenta, iban a repetir el sorteo, pero Helio dijo que le bastaba con que sacaran a Rodas a la luz"; de Delos: "en el nacimiento de Apolo y Ártemis, emergió del mar". Son causas heroicas las de Salamina de Chipre o las de Argos de Anfíloco; pues una la fundó Teucro en su destierro; la otra, Anfíloco, el de Anfiarao; también muchas otras ciudades de las griegas tienen causas heroicas como esas. Hamanas son las causas que se cuentan de Babilonia, que la fundó Semíramis, la de Nino (Menandro el Rétor, 1996, pp. 129-130, 357, 15-32)

De estas causas, la más gloriosa es la divina; luego, la heroica y, por último, la humana.

De esas causas mismas, las divinas y heroicas son míticas; las humanas, más verosímiles. Así que las humanas hay que amplificarlas, y las divinas y heroicas hay que hacerlas verosímiles y amplificarlas (Menandro el Rétor, 1996, p. 132, 359, 9-12)

\section{Bibliografía}

Anónimo. (1977). Sobre lo sublime. (J. Alcina-Clota, tr.). Barcelona: Bosch.

Aristóteles. (1992). Poética de Aristóteles, edición trilingüe por Valentín García Yebra. (1ed.). Madrid: Editorial Gredos.

Aristóteles. (1994). Reproducción de los animales. (E. Sánchez, tr.). Madrid: Editorial Gredos. Aristóteles. (1995). Física. (G. de Echandía, tr.). Madrid: Editorial Gredos.

Ernout, A. y Meillet, A. (1967). Dictionnaire étymoligique de la langue latina. Histoire des mots. (4 ed.). Paris: Librairie C. Klincksieck.

Hermógenes. (1993). Sobre las formas de estilo. (C. Ruíz-Montero, tr.). (1 ed.). Madrid: Editorial Gredos.

Isidoro de Sevilla. (2009). Etimologías. (J. Oroz-Reta, tr.). Madrid: Biblioteca de Autores Cristianos.

Menadro el Rétor. (1996). Dos tratados de retórica epidíctica. [Introducción de Fernando Gascó]. (M. García-García y J. Gutiérrez-Calderón, trs.). Madrid: Editorial Gredos.

Nietzsche, F. (1952). El origen de la tragedia. (3 ed.). Buenos Aires: Espasa-Calpe.

Pabón S. de Urbina, J. M. (1995). Diccionario manual griego-español. (17 ed.). Barcelona: Briblograf.

Sebastián-Yarza, F. I. (1964). Diccionario griego-español. Barcelona: Editorial Ramón Sopena. 